\title{
Evaluation of Some Alfalfa (Medicago sativa L.) Germplasm for Yield and Yield Component Traits
}

\author{
S. A. Arab, M.H. El Shal and N. M. Hamed* \\ National Gene Bank and Forage Crops Res. Dept., Field \\ Crops Res. Inst., Agricultural Research Center, Cairo, Egypt.
}

\begin{abstract}
GORTY-TWO alfalfa (Medicago sativa L.) landraces collected from different regions in Egypt and three commercial varieties were evaluated in this study. The data collected and analyzed were for plant height, number of tillers per $\mathrm{m}^{2}$, leaf to stem ratio, green forage weight and dry matter weight. The results indicated that plant height, number of tillers per square meter $\left(\mathrm{m}^{-}{ }^{2}\right)$ green forage yield, and dry matter weight were higher in the second year than the first year. There was a strong positive correlation between green forage yield with plant height and number of tillers per $\mathrm{m}^{2}$ in addition, between dry forage yield with plant height and number of tillers per $\mathrm{m}^{2}$. There was also a highly significant positive relationship between green forage yield and dry forage yield. Using cluster analysis all genotypes were divided into two groups. The first group contained varieties Ismailia 1, Siwa and Nubaria, while the second group contained other genotypes collected from different regions. Maximum similarity index was recorded between genotypes (S18 and S09), while minimum similarity was between genotypes (D12 and Siwa).
\end{abstract}

Keywords: Alfalfa, Genotypes, Varieties, Egypt, Correlation, Cluster analysis, Maximum similarity and minimum similarity.

Alfalfa (Medicago sativa L.) is widely distributed worldwide and grown in highly contrasting environments. This extensive geographical adaptation promotes genetic variation and gives breeders the possibility of using highly diverse gene pools (Maureira et al., 2004).

Genetic diversity among initial selection materials is essential for successful breeding and creation of new cultivars. For the estimation of genetic diversity, different criteria, as morphological, agronomic and physiological characters, pedigree records, molecular markers or a combination of criteria are used. Erosion of diversity in most of the cultivated species emphasizes the need to collect and investigate new germplasm as genetic resources for future breeding programs.

Crop improvement through plant breeding is greatly dependent upon the amount of genetic variation in the available breeding material, type of gene action, the extent of variation, and the heritability of the traits. Such knowledge may also suggest the ways to use germplasm to create new varieties (Bowley \& Christie, 1981). 
Alfalfa has high green and dry matter yield with considerably high protein and vitamin content (Sabanci, 2009). Yield of alfalfa is the result of yield components effect: number of plants per area, number of stems per plant, weight and height of individual stem (Fick et al., 1988). In the western desert Oases of Egypt alfalfa is widely planted as a forage crop. Most often it is harvested for green fed hay, making silage and less frequently as pasture as it has the highest nutritive value among the forage crops. Alfalfa accessions collected from different geographic regions of the western desert Oases, showed high genetic variation as well as accession derived from the different ancestors (Arab \& El Shal, 2013).

The objectives of this study were to determine the productivity of different alfalfa genotypes collected from different regions of the western desert in comparison with varieties. In addition, the genetic diversity among these genotypes was evaluated for further use in plant breeding.

\section{Materials and Methods}

Forty-two landraces of alfalfa of different geographic origin were evaluated in this study (Table 1). Three commercial varieties were also included namely Ismailia 1, Siwa and Nubaria. This study was carried out at the Experimental Fields of the New Valley Agricultural Research Station, during three seasons 2011, 2012 and 2013. The genotypes and varieties were sown in an augmented design on the second of November 2011. The field trial was arranged in a randomized complete block design with four replications. The plot area was $6 \mathrm{~m}^{2}$ and the seed was sown at the rate of $20 \mathrm{~kg} \mathrm{fed}^{-1}$ in rows $20 \mathrm{~cm}$ apart. Nine cuts were performed during the second growing season $(2 / 02,12 / 03,22 / 04,27 / 05$, $1 / 07,5 / 08,10 / 09,15 / 10$, and 20/11in 2011/2012) and nine cuts during the third growing season $(25 / 12,10 / 02,25 / 03,12 / 05,13 / 06,15 / 07,17 / 08,18 / 09$ and $20 / 10$ in 2012/2013).

The characters recorded were plant height, number of tillers per $\mathrm{m}^{2}$, leaf to stem ratio $(\%)$, green forage weight (ton fed ${ }^{-1}$ ) and dry matter weight (ton fed ${ }^{-1}$ ).

The statistical analysis and the relationship between the germplasm were measured by calculating their Euclidean distance and complete linkage using SYSTAT version 7.0 (Wilkinson 1997). 
EVALUATION OF SOME ALFALFA (MEDICAGO SATIVA L.) ...

TABLE 1. List of alfalfa germplasm, collection site and GPS data.

\begin{tabular}{|c|c|c|c|c|c|c|c|}
\hline No & Name & $\begin{array}{c}\text { Collection site } \\
\text { from Egypt }\end{array}$ & & tude & & & $\begin{array}{c}\begin{array}{c}\text { Elevation } \\
(\mathbf{k m})\end{array} \\
\end{array}$ \\
\hline 1 & D02 & New Valley - El Dakhla & 25 & 42 & 28 & 44 & 145 \\
\hline 2 & D03 & New Valley - El Dakhla & 25 & 28 & 28 & 17 & 118 \\
\hline 3 & D04 & New Valley - El Dakhla & 25 & 45 & 28 & 39 & 145 \\
\hline 4 & D05 & New Valley - El Dakhla & 25 & 53 & 28 & 29 & 92 \\
\hline 5 & D06 & New Valley - El Dakhla & 25 & 42 & 28 & 54 & 107 \\
\hline 6 & D07 & New Valley - El Dakhla & 25 & 42 & 28 & 54 & 107 \\
\hline 7 & D08 & New Valley - El Dakhla & 25 & 39 & 28 & 55 & 117 \\
\hline 8 & D09 & New Valley - El Dakhla & 25 & 36 & 28 & 54 & 101 \\
\hline 9 & D10 & New Valley - El Dakhla & 25 & 34 & 28 & 55 & 98 \\
\hline 10 & D12 & New Valley - El Dakhla & 25 & 37 & 28 & 52 & 113 \\
\hline 11 & D13 & New Valley - El Dakhla & 25 & 33 & 28 & 47 & 129 \\
\hline 12 & D16 & New Valley - El Dakhla & 25 & 30 & 28 & 2 & 117 \\
\hline 13 & D17 & New Valley - El Dakhla & 25 & 30 & 28 & 3 & 115 \\
\hline 14 & D18 & New Valley - El Dakhla & 25 & 32 & 28 & 8 & 137 \\
\hline 15 & F02 & New Valley - Al Farafra & 26 & 47 & 27 & 48 & 101 \\
\hline 16 & F03 & New Valley - Al Farafra & 26 & 49 & 27 & 51 & 96 \\
\hline 17 & F04 & New Valley - Al Farafra & 26 & 52 & 27 & 52 & 114 \\
\hline 18 & F05 & New Valley - Al Farafra & 27 & 3 & 27 & 55 & 67 \\
\hline 19 & F06 & New Valley - Al Farafra & 27 & 3 & 27 & 52 & 60 \\
\hline 20 & F07 & New Valley - Al Farafra & 27 & 4 & 27 & 54 & 61 \\
\hline 21 & F08 & New Valley - Al Farafra & 27 & 8 & 27 & 56 & 48 \\
\hline 22 & F09 & New Valley - Al Farafra & 27 & 3 & 27 & 57 & 46 \\
\hline 23 & F11 & New Valley - Al Farafra & 26 & 51 & 27 & 57 & 98 \\
\hline 24 & F12 & New Valley - Al Farafra & 27 & 4 & 27 & 57 & 77 \\
\hline 25 & F14 & New Valley - Al Farafra & 27 & 6 & 27 & 57 & 58 \\
\hline 26 & F18 & New Valley - Al Farafra & 26 & 50 & 27 & 51 & 95 \\
\hline 27 & F19 & New Valley - Al Farafra & 26 & 52 & 27 & 48 & 85 \\
\hline 28 & F21 & New Valley - Al Farafra & 27 & 7 & 27 & 57 & 51 \\
\hline 29 & S01 & New Valley - El Dakhla & 29 & 11 & 25 & 29 & -15 \\
\hline 30 & S02 & Matrouh- Siwa & 29 & 11 & 25 & 29 & -16 \\
\hline 31 & S04 & Matrouh- Siwa & 29 & 11 & 25 & 29 & -15 \\
\hline 32 & S05 & Matrouh- Siwa & 29 & 11 & 25 & 29 & -16 \\
\hline 33 & S06 & Matrouh- Siwa & 29 & 10 & 25 & 29 & -15 \\
\hline 34 & S07 & Matrouh- Siwa & 29 & 12 & 25 & 29 & -16 \\
\hline 35 & S08 & Matrouh- Siwa & 29 & 11 & 25 & 29 & -17 \\
\hline 36 & S09 & Matrouh- Siwa & 29 & 12 & 25 & 29 & -19 \\
\hline 37 & S10 & Matrouh-Siwa & 29 & 13 & 25 & 25 & -13 \\
\hline 38 & S16 & Matrouh- Siwa & 29 & 16 & 25 & 18 & -15 \\
\hline 39 & S18 & Matrouh- Siwa & 29 & 11 & 25 & 32 & -16 \\
\hline 40 & S11 & Matrouh- Siwa & 29 & 13 & 25 & 24 & -12 \\
\hline 41 & S12 & Matrouh- Siwa & 29 & 13 & 25 & 24 & -9 \\
\hline 42 & S13 & Matrouh- Siwa & 29 & 13 & 25 & 24 & -11 \\
\hline 43 & Ismailia 1 & Variety & & & & & \\
\hline 44 & Siwa & Variety & & & & & \\
\hline 45 & Nubaria & Variety & & & & & \\
\hline
\end{tabular}

Egypt. J. Agron. 37, No. 1 (2015) 


\section{Results and Discussion}

The results showed significant differences between the years for yield and yield components indicating the presence of differences among the genotypes for all characters.

\section{Plant height}

The average value of plant height (Table 2) show that maximum plant height was recorded for the variety Nubaria $(52.35 \mathrm{~cm})$ followed by Ismailia 1 with $(52.00 \mathrm{~cm})$ while the minimum plant height was recorded for D06 $(45.78 \mathrm{~cm})$. Variation in plant height is genotypic character and; therefore, expressed in the form of better adaptability to environmental conditions.

\section{Number of tillers}

The average value of number of tillers per $\mathrm{m}^{2}$ is presented in Table 2 revealed that maximum number of tillers per $\mathrm{m}^{2}$ was noted in Nubaria (139.78) followed by Siwa with (137.54). Minimum number of tillers per $\mathrm{m}^{2}(53.4 \mathrm{~cm})$ was attained by genotype D06 (90.74). The differences among various genotypes and cultivars may be due to genetic makeup.

\section{Leaf/stem ratio \%}

The result presented in Table 2 revealed that all collected genotypes provided significantly higher leaf/stem ratio than the three varieties used in this study. There was great variability between collected genotypes for leaf/stem ratio.

\section{Green forage yield}

Green forage yield was higher in the second year $\left(52.02\right.$-ton fed $\left.^{-1}\right)$ than the first (35.39-ton $\left.\mathrm{fed}^{-1}\right)$, but the difference was not statistically significant. Because alfalfa is a perennial crop, it is possible to have greater yield in subsequent years compared to the previous year in the first 2-3 years. Maximum green forage was produced by Nubaria $\left(65.88\right.$ ton $\left.^{-1} \mathrm{fe}^{-1}\right)$ followed by Ismailia 1 with $\left(64.88\right.$ ton-fed $\left.^{-1}\right)$ while D06 (30.38-ton $\left.\mathrm{fed}^{-1}\right)$ had the minimum green forage yield.

\section{Dry forage yield}

The mean dry forage yield for all genotypes (Table 3) showed that Nubaria produced maximum values of (18.74 ton fed $\left.{ }^{-1}\right)$ followed by Siwa with (18.58 ton $\left.\mathrm{fed}^{-1}\right)$, while genotype D06 produced the minimum dry forage yield $\left(7.90\right.$ ton fed $\left.{ }^{-1}\right)$. 
EVALUATION OF SOME ALFALFA (MEDICAGO SATIVA L.) ...

TABLE 2. Mean performance for yield components of 45 alfalfa genotypes in 2011/12 and 2012/13 growing seasons.

\begin{tabular}{|c|c|c|c|c|c|c|c|c|c|}
\hline \multirow{2}{*}{ Genotypes` } & \multicolumn{3}{|c|}{ Plant height, cm } & \multicolumn{3}{|c|}{ Number of tillers $\mathbf{m}^{-2}$} & \multicolumn{3}{|c|}{ Leaf/stem ratio\% } \\
\hline & $2011 / 2012$ & $2012 / 2013$ & Average & $2011 / 2012$ & $2012 / 2013$ & Average & $2011 / 2012$ & $2012 / 2013$ & Average \\
\hline D02 & 47.70 & 48.16 & 47.93 & 90.68 & 106.84 & 98.76 & 43.85 & 43.09 & 43.47 \\
\hline D03 & 46.53 & 47.72 & 47.12 & 91.95 & 103.44 & 97.69 & 45.48 & 43.72 & 44.60 \\
\hline D04 & 49.50 & 47.91 & 48.70 & 105.38 & 106.28 & 105.83 & 42.78 & 43.88 & 43.33 \\
\hline D05 & 46.53 & 47.06 & 46.79 & 90.05 & 98.00 & 94.03 & 45.78 & 44.53 & 45.15 \\
\hline D06 & 44.50 & 47.06 & 45.78 & 81.98 & 99.50 & 90.74 & 47.15 & 44.59 & 45.87 \\
\hline D07 & 45.75 & 47.22 & 46.48 & 86.93 & 100.72 & 93.82 & 46.55 & 44.78 & 45.67 \\
\hline D08 & 47.58 & 48.00 & 47.79 & 94.00 & 106.78 & 100.39 & 44.65 & 44.06 & 44.36 \\
\hline D09 & 44.78 & 48.22 & 46.50 & 82.55 & 106.59 & 94.57 & 47.48 & 43.31 & 45.39 \\
\hline D10 & 44.98 & 48.09 & 46.53 & 101.93 & 107.28 & 104.60 & 47.15 & 43.41 & 45.28 \\
\hline D12 & 45.90 & 47.16 & 46.53 & 90.55 & 118.03 & 104.29 & 45.68 & 44.34 & 45.01 \\
\hline D13 & 46.15 & 48.56 & 47.36 & 86.38 & 113.84 & 100.11 & 45.98 & 42.88 & 44.43 \\
\hline D16 & 49.78 & 48.34 & 49.06 & 112.23 & 107.19 & 109.71 & 41.83 & 43.28 & 42.55 \\
\hline D17 & 51.53 & 49.09 & 50.31 & 122.60 & 116.44 & 119.52 & 41.50 & 42.28 & 41.89 \\
\hline D18 & 46.98 & 49.34 & 48.16 & 98.25 & 116.88 & 107.56 & 45.28 & 41.69 & 43.48 \\
\hline F02 & 48.85 & 49.41 & 49.13 & 110.55 & 115.00 & 112.78 & 42.58 & 41.16 & 41.87 \\
\hline F03 & 48.50 & 48.66 & 48.58 & 107.43 & 103.34 & 105.38 & 43.13 & 43.31 & 43.22 \\
\hline F04 & 46.38 & 49.34 & 47.86 & 95.63 & 112.34 & 103.98 & 45.78 & 42.56 & 44.17 \\
\hline F05 & 45.53 & 48.16 & 46.84 & 86.45 & 106.22 & 96.33 & 47.25 & 43.34 & 45.30 \\
\hline F06 & 45.95 & 49.28 & 47.62 & 90.25 & 112.22 & 101.23 & 46.30 & 43.00 & 44.65 \\
\hline F07 & 49.03 & 49.09 & 49.06 & 117.58 & 107.24 & 112.41 & 42.65 & 42.78 & 42.72 \\
\hline F08 & 51.05 & 49.44 & 50.24 & 127.30 & 113.91 & 120.60 & 41.50 & 42.47 & 41.98 \\
\hline F09 & 48.60 & 48.53 & 48.57 & 105.18 & 107.19 & 106.18 & 43.53 & 43.56 & 43.54 \\
\hline F11 & 47.60 & 49.97 & 48.78 & 99.95 & 115.59 & 107.77 & 44.23 & 42.09 & 43.16 \\
\hline $\mathrm{F} 12$ & 47.28 & 49.81 & 48.54 & 104.80 & 117.03 & 110.92 & 44.23 & 42.22 & 43.22 \\
\hline F14 & 49.65 & 49.50 & 49.58 & 109.93 & 114.41 & 112.17 & 42.53 & 42.78 & 42.65 \\
\hline F18 & 49.95 & 48.53 & 49.24 & 115.50 & 107.97 & 111.73 & 41.93 & 43.00 & 42.46 \\
\hline $\mathrm{F} 19$ & 50.65 & 47.69 & 49.17 & 116.30 & 99.66 & 107.98 & 41.23 & 44.13 & 42.68 \\
\hline$F 21$ & 47.80 & 49.09 & 48.45 & 94.13 & 113.16 & 103.64 & 43.63 & 42.75 & 43.19 \\
\hline So1 & 47.43 & 48.94 & 48.18 & 93.70 & 111.50 & 102.60 & 44.65 & 42.66 & 43.65 \\
\hline S02 & 46.83 & 48.84 & 47.83 & 94.53 & 110.91 & 102.72 & 44.55 & 42.91 & 43.73 \\
\hline S04 & 47.33 & 47.97 & 47.65 & 90.50 & 100.59 & 95.55 & 44.83 & 44.19 & 44.51 \\
\hline S05 & 48.38 & 49.53 & 48.95 & 94.73 & 112.66 & 103.69 & 43.63 & 42.59 & 43.11 \\
\hline So6 & 50.40 & 48.78 & 49.59 & 112.85 & 106.91 & 109.88 & 41.38 & 43.25 & 42.31 \\
\hline S07 & 49.23 & 49.69 & 49.46 & 111.75 & 114.28 & 113.02 & 42.45 & 42.28 & 42.37 \\
\hline S08 & 49.25 & 49.50 & 49.38 & 109.75 & 115.16 & 112.45 & 42.65 & 42.09 & 42.37 \\
\hline Sog & 49.78 & 49.84 & 49.81 & 112.33 & 115.13 & 113.73 & 42.00 & 42.28 & 42.14 \\
\hline $\mathrm{S} 10$ & 48.80 & 49.38 & 49.09 & 111.55 & 113.38 & 112.46 & 42.65 & 42.44 & 42.54 \\
\hline S16 & 48.68 & 49.56 & 49.12 & 98.25 & 114.47 & 106.36 & 43.25 & 42.28 & 42.77 \\
\hline S18 & 48.53 & 50.78 & 49.65 & 106.20 & 120.63 & 113.41 & 43.30 & 41.19 & 42.24 \\
\hline S11 & 48.80 & 50.84 & 49.82 & 109.23 & 124.34 & 116.78 & 43.15 & 41.28 & 42.22 \\
\hline S12 & 49.13 & 51.06 & 50.09 & 111.43 & 123.25 & 117.34 & 42.63 & 39.81 & 41.22 \\
\hline $\mathrm{S} 13$ & 48.68 & 49.16 & 48.92 & 101.95 & 114.47 & 108.21 & 43.63 & 42.72 & 43.17 \\
\hline Ismailia 1 & 52.40 & 51.59 & 52.00 & 142.30 & 131.22 & 136.76 & 39.95 & 40.38 & 40.16 \\
\hline Siwa & 52.10 & 49.94 & 51.02 & 142.18 & 132.91 & 137.54 & 40.08 & 40.59 & 40.33 \\
\hline Nubaria & 52.80 & 51.91 & 52.35 & 142.98 & 136.59 & 139.78 & 39.45 & 40.19 & 39.82 \\
\hline Mean & 48.30 & 49.02 & 48.66 & 104.50 & 112.25 & 108.38 & 43.68 & 42.71 & 43.20 \\
\hline LSD at 0.05 & 3.01 & 2.66 & 2 & 20.66 & 15.27 & 15.39 & 2.80 & 2.06 & 2.05 \\
\hline
\end{tabular}

Egypt. J. Agron. 37, No. 1 (2015) 
TABLE 3. Mean performance for yield components of 45 alfalfa genotypes in 2011/12 and 2012/13 growing seasons.

\begin{tabular}{|c|c|c|c|c|c|c|}
\hline \multirow{2}{*}{ Genotypes } & \multicolumn{3}{|c|}{ 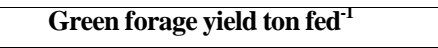 } & \multicolumn{3}{|c|}{ Dry forage yield ton fed ${ }^{-1}$} \\
\hline & $2011 / 2012$ & $2012 / 2013$ & Average & 2011/2012 & $2012 / 2013$ & Average \\
\hline D02 & 22.75 & 48.50 & 35.63 & 6.00 & 12.92 & 9.46 \\
\hline D03 & 24.00 & 47.50 & 35.75 & 6.46 & 12.57 & 9.51 \\
\hline D04 & 38.25 & 47.25 & 42.75 & 10.42 & 12.58 & 11.50 \\
\hline D05 & 25.25 & 41.50 & 33.38 & 6.31 & 11.11 & 8.71 \\
\hline D06 & 17.25 & 43.50 & 30.38 & 4.26 & 11.54 & 7.90 \\
\hline D07 & 19.25 & 43.00 & 31.13 & 5.18 & 11.48 & 8.33 \\
\hline D08 & 26.00 & 47.50 & 36.75 & 7.03 & 12.84 & 9.93 \\
\hline D09 & 15.75 & 48.50 & 32.13 & 3.99 & 12.97 & 8.48 \\
\hline D10 & 19.00 & 49.00 & 34.00 & 4.89 & 12.98 & 8.94 \\
\hline D12 & 21.75 & 42.25 & 32.00 & 5.70 & 11.18 & 8.44 \\
\hline D13 & 21.00 & 53.75 & 37.38 & 5.60 & 14.55 & 10.07 \\
\hline D16 & 42.75 & 48.75 & 45.75 & 11.82 & 13.04 & 12.43 \\
\hline D17 & 52.75 & 56.00 & 54.38 & 14.90 & 15.39 & 15.15 \\
\hline D18 & 29.25 & 55.25 & 42.25 & 8.14 & 14.97 & 11.55 \\
\hline F02 & 40.75 & 54.50 & 47.63 & 11.36 & 14.95 & 13.15 \\
\hline F03 & 37.50 & 46.00 & 41.75 & 10.36 & 12.09 & 11.23 \\
\hline F04 & 26.25 & 53.50 & 39.88 & 7.11 & 14.57 & 10.84 \\
\hline F05 & 18.25 & 47.25 & 32.75 & 4.85 & 12.62 & 8.74 \\
\hline F06 & 21.75 & 52.50 & 37.13 & 5.84 & 14.21 & 10.02 \\
\hline F07 & 46.25 & 50.25 & 48.25 & 12.83 & 13.46 & 13.14 \\
\hline F08 & 55.25 & 53.75 & 54.50 & 15.53 & 14.60 & 15.07 \\
\hline F09 & 36.00 & 49.25 & 42.63 & 10.08 & 13.20 & 11.64 \\
\hline F11 & 30.75 & 55.25 & 43.00 & 8.55 & 15.27 & 11.91 \\
\hline F12 & 34.00 & 56.00 & 45.00 & 9.59 & 15.44 & 12.52 \\
\hline F14 & 40.75 & 53.25 & 47.00 & 11.39 & 14.32 & 12.86 \\
\hline F18 & 47.50 & 48.00 & 47.75 & 13.45 & 12.81 & 13.13 \\
\hline F19 & 47.75 & 43.00 & 45.38 & 13.56 & 11.32 & 12.44 \\
\hline F21 & 27.25 & 52.75 & 40.00 & 7.39 & 14.42 & 10.91 \\
\hline S01 & 26.25 & 51.25 & 38.75 & 7.09 & 13.72 & 10.40 \\
\hline S02 & 28.25 & 51.00 & 39.63 & 7.72 & 13.74 & 10.73 \\
\hline S04 & 25.00 & 43.50 & 34.25 & 6.91 & 11.53 & 9.22 \\
\hline S05 & 28.75 & 53.50 & 41.13 & 7.99 & 14.57 & 11.28 \\
\hline S06 & 44.00 & 49.00 & 46.50 & 12.31 & 13.30 & 12.81 \\
\hline S07 & 43.25 & 54.25 & 48.75 & 12.12 & 14.68 & 13.40 \\
\hline S08 & 43.50 & 54.50 & 49.00 & 12.19 & 15.04 & 13.62 \\
\hline S09 & 42.25 & 54.50 & 48.38 & 11.89 & 14.90 & 13.40 \\
\hline S10 & 42.00 & 53.00 & 47.50 & 11.71 & 14.34 & 13.02 \\
\hline S16 & 31.25 & 54.75 & 43.00 & 8.79 & 15.06 & 11.92 \\
\hline S18 & 38.50 & 59.25 & 48.88 & 10.91 & 16.38 & 13.65 \\
\hline S11 & 41.75 & 61.50 & 51.63 & 11.95 & 17.14 & 14.55 \\
\hline S12 & 44.00 & 61.00 & 52.50 & 12.71 & 17.01 & 14.86 \\
\hline S13 & 35.75 & 53.50 & 44.63 & 9.83 & 14.44 & 12.14 \\
\hline Ismailia 1 & 63.50 & 66.25 & 64.88 & 18.21 & 18.87 & 18.54 \\
\hline Siwa & 65.50 & 65.00 & 65.25 & 18.83 & 18.33 & 18.58 \\
\hline Nubaria & 64.25 & 67.50 & 65.88 & 18.42 & 19.05 & 18.74 \\
\hline Mean & 35.39 & 52.02 & 43.71 & 9.83 & 14.12 & 11.97 \\
\hline LSD at 0.05 & 17.40 & 10.93 & 11.73 & 5.15 & 3.07 & 3.59 \\
\hline
\end{tabular}

Egypt. J. Agron. 37, No. 1 (2015) 
In general, plant height is an important yield component for alfalfa and it is often used as a criterion when choosing superior genotypes in an early stage of selection (Tuckak et al., 2008). Green yield was higher in the second year $\left(53.56 \mathrm{t} \mathrm{ha}^{-1}\right)$ than the first $\left(46.27 \mathrm{t} \mathrm{ha}^{-1}\right)$ which is in accordance with the results reported by Sabanci et al. (2013). Alfalfa forage yield depends upon three factors including plant numbers per unit area, stem numbers per plant and single-stem yield (Smith \& Hamel, 2005). Alfalfa yield is the result of yield components effect: number of plants per unit area, number of stems per plant, weight and height of individual stem (Fick et al., 1988), while alfalfa quality is a complex trait determined by morphological, chemical and physiological composition (Kirilov, 2001).

Correlations of yield with different yield components of alfalfa genotypes

The correlation coefficients calculated from our results revealed a strong positive correlation between green forage yield with plant height and number of tillers per $\mathrm{m}^{2}$ as well as between dry forage yield with plant height and number of tillers per $\mathrm{m}^{2}$. There was also a highly significant positive relationship between green forage yield and dry forage yield (Table 4) .

TABLE 4. Correlation coefficients of yield and some yield components of 45 alfalfa genotypes.

\begin{tabular}{|l|c|c|c|c|}
\hline & $\begin{array}{c}\text { Plant } \\
\text { height }\end{array}$ & $\begin{array}{c}\text { Number of } \\
\text { tillers }\end{array}$ & $\begin{array}{c}\text { Leaf/stem } \\
\text { ratio }\end{array}$ & $\begin{array}{c}\text { Green forage } \\
\text { yield }\end{array}$ \\
\hline Number of tillers & $0.925^{* *}$ & & & \\
\hline Leaf/stem ratio & $-0.981^{* *}$ & $-0.925^{* *}$ & & \\
\hline Green forage yield & $0.969 * *$ & $0.974 * *$ & $-0.965 * *$ & \\
\hline Dry forage yield & $0.969 * *$ & $0.974^{* *}$ & $-0.965^{* *}$ & $0.999^{* *}$ \\
\hline
\end{tabular}

Selection of promising genotypes in a breeding program based on various criteria, most importantly final crop yield and its quality. Relationships between yield and yield contributing traits also plays an important role (Diz et al., 1994; Guler et al., 2001; Mohammadi et al., 2003 and Rabiei et al., 2004).

\section{Cluster analysis}

Measurement of genetic distance should be very important for breeding when it is based on a broad range of traits relevant to breeding objectives. Cluster analysis for investigated traits showed diversity among investigated alfalfa genotypes. All genotypes are divided into two groups at a distance of 9.004. The first group contains varieties Ismailia 1, Siwa and Nubaria. The second group contains other genotypes collected from different regions. Leaf/stem ratio is valuable in splitting the studied genotypes into two groups less to $40.33 \%$ included the first group, however up than $40.33 \%$ included the second group (Fig.1). 
The second group was divided into two subgroups at a distance of 2.020. The remaining accessions of El Dakhla (D10 and D12) delimited in a separate subgroup, while other accessions were separated in the other subgroup. Maximum similarity was recorded between genotypes (S18 and S09). Minimum similarity was computed between genotypes (D12 and Siwa).

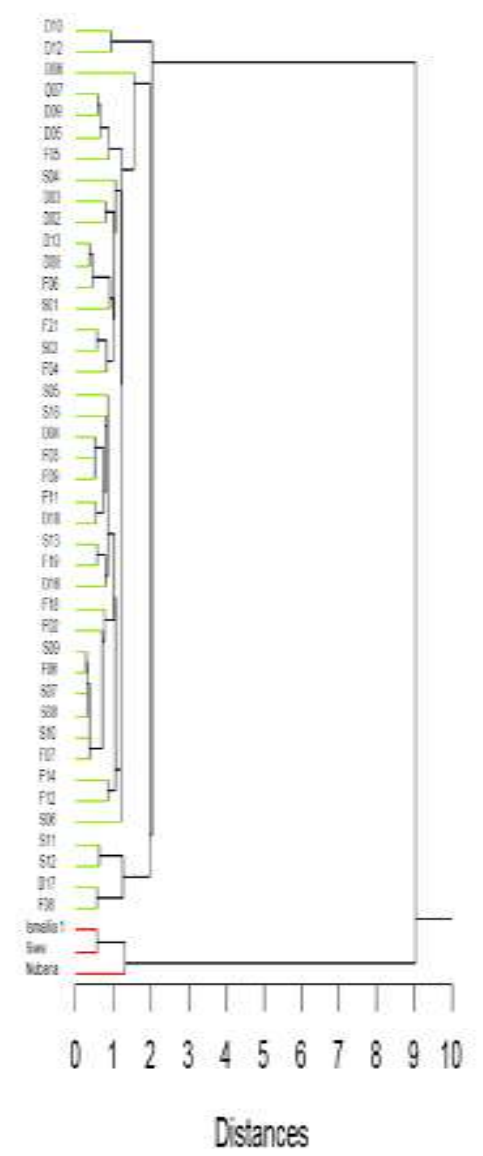

Fig. 1. Phenogram showing the relationships between 45 genotypes of alfalfa, using distance metric of 1- Euclidean correlation coefficient and average linkage method.

\section{Conclusion}

It could be concluded that the three commercial varieties take different branchES from the forty-two germplasm. In addition, forty-two germplasm was divided into different branches and indicated that the collections germplasm will widen the genetic base of alfalfa in Egypt and will help plant breeders for the possibility of using highly diverse gene pools to induce new varieties for yield and yield components using suitable methods of hybridization.

Egypt. J. Agron. 37, No. 1 (2015) 
Acknowledgment : The authors express their deepest appreciation to the Agricultural Research and Development Fund (ARDF) for the financial support of this research under the project "Sustainable utilization of Agriculture Biodiversity to Develop the Local Communities in the Western Desert".

\section{References}

Arab, S. A. and El Shal, M.H. (2013) Diversity of alfalfa in the Oases of Western Desert in Egypt. Egypt. J. Plant Breed. 17 (4), 99-112.

Bowley, S.R. and Christie, B.R. (1981) Inheritance of dry matter yield in a heterozygous population of alfalfa. Can. J. Plant. Sci. 61, 313-318.

Diz, D. A., Wofford, D.S. and Schank, S.C. (1994) Correlation and path-coefficient analyses of seed-yield components in pearl millet $\times$ elephant grass hybrids. Theoretical and Applied Genetics, 89,112-115.

Fick, G.W., Holt, D.A. and Lugg, D.G. (1988) "Environmental Physiology and Crop Growth. Alfalfa and Alfalfa Improvement" (Monograph 29). American Society of Agronomy Inc, Madison, Wisconsin, USA.

Guler, M., Adak, M.S. and Ulukan, H. (2001) Determining relationships among yield and some yield components using path coefficient analysis in chickpea (Cicer arietinum L.). European Journal of Agronomy 14, 161-166.

Kirilov, A. (2001) Lucerne quality and possibilities for its estimation. Proc. of the XIV Eucarpia Medicago spp. Group Meeting, Zargoza, Spain, 231-234 p.

Maureira, I. J., Ortega, F., Campos, H. and Osborn, T. C. (2004) Population structure and combining ability of diverse Medicago sativa germplasms. Theo. App. Genet. 109 (4), 775-782.

Mohammadi, S.A., Prasanna, B.M. and Singh, N.N. (2003) Sequential path model for determining interrelationships among grain yield and related characters in maize. Crop Sci. 43, 1690-1697.

Rabiei, B., Valizadeh, M., Gharayazie, B. and Moghaddam, M. (2004) Evaluation of selection indices for improving rice grain shape. Field Crops Research, 89, 359-367.

Sabanci, C. O. (2009) "Forage Legumes". Yuzuncu Y1l Uni. Foundation. Publ. No. 2. 224 p. Van, Turkey.

Sabanci, C. O., Ertu , M. M. and Celeb , S. Z. (2013) Collection, conservation and evaluation for forage yield of alfalfa landraces grown in east Anatolia. Turkish Journal of Field Crops, 18(1), 46-51

Smith, D.L. and Hamel, C. (2005) "Crops yield, Physiology and Processes". (Trans.) Y. Imam and M.G. Seghatoleslami (Ed.). Shiraz University Press. Iran .

Tuckak, M., Popovic, S., Cupic, T., Grljusic, S., Bolaric, S. and Kozumplik, V. (2008) Genetic diversity of alfalfa (Medicago spp.) estimated by molecular markers and morphological characters. Period Biol, 110, 243-249.

Egypt. J. Agron. 37, No. 1 (2015) 
Wilkinson, L. (1997) SYSTAT: "The System Analysis for Statistics". SYSTAT, Evanston, III.

\section{تقييم بعض التراكيب الوراثية من البرسيم الحجازي للمحصول ومكوناته

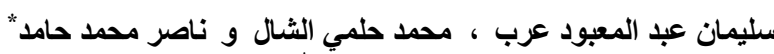

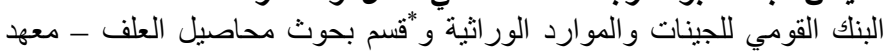

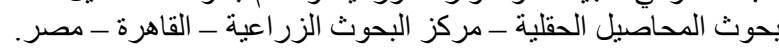

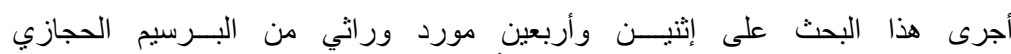

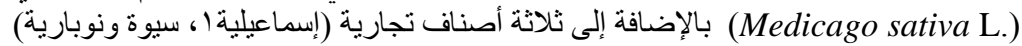

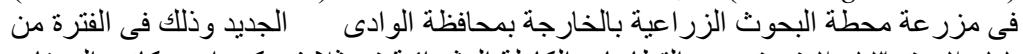

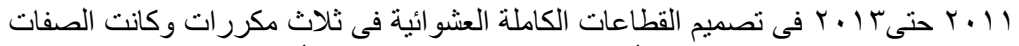

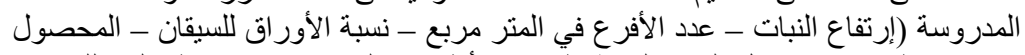

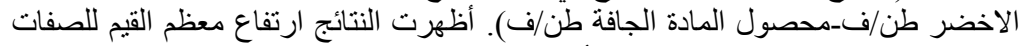

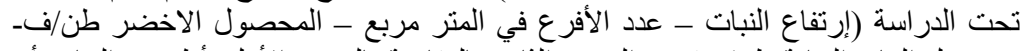

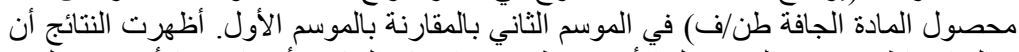

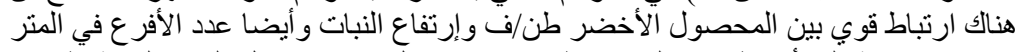

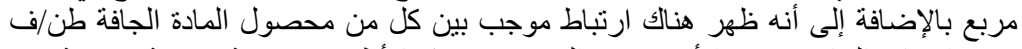

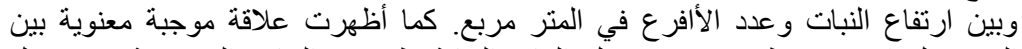

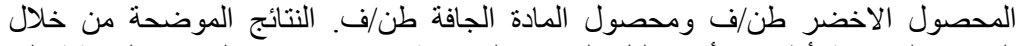

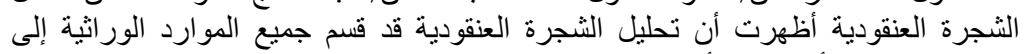

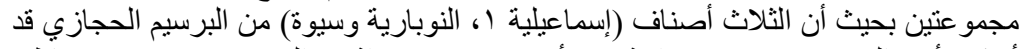



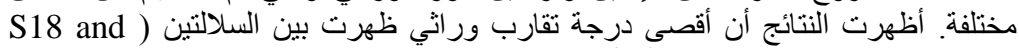

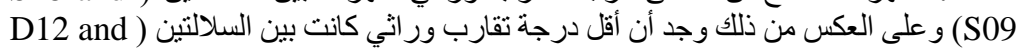

.(Siwa 